\title{
パーソントリップ調査における回答誤差とその発生要因
}

\section{Response Bias in Person Trip Surveys}

名取義和*、谷下雅義 $* *$ 、鹿島茂***

By Yoshikazu NATORI*, Masayoshi TANISHITA** and Shigeru KASHIMA***

\section{1.はじめに}

\section{(1) 研究の目的}

総合都市交通体系のマスタープラン策定を目的として、 都市圏における交通需要を予測するために、パーソント リップ調査（以下 PT 調査という）が用いられるように なって 30 年以上が経過している。この間、PT 調査につ いてのさまざまな問題点が指摘されている。その一つが 調查結果の精度 (回答誤差) についてである。

この問題は、PT 調査が一般の人々に十分認識されて いないことから、回答者への負担が大きくなること、そ してその結果として、無回答率の増加や誤答の含まれて いる可能性が高くなる（回答結果の誤差が大きくなる） ことによると考えられる ${ }^{1)}$ 。

PT 調査に対する信頼性を高めるための方法として、 (1)回答者への負担を考慮した質問票の設計、(2)回答結果 の精度に対する検討、がある。このうち(1)については、 調查の継続性の問題などから大幅な変更は難しいのが現 状である。また(2)については、杉恵ら 2) 3) や中村ら ${ }^{4)}$ によって、PT 調査よりもアクティビティ・ダイアリー 調査の方がより詳細なトリップデータを得られることが 指摘されている。すなわち、PT 調査においてトリップ の抜け落ちがあることが分かっている。しかしながら、 どのような要因の下で、どういった種類のトリップが抜 け落ちているのかは判明していない。

そこで、本研究は、PT 調査で抜け落ちるトリップに 注目し、それが(1)どの程度あるのか、(2)どのような種類 のものであるのか、(3)どのような要因のもとで発生する のか、について分析することを目的とする。

\section{（2）研究の方法}

本研究では、PT 調查票 (以下 PT 票という) とアクテ イビティ調査票（以下 $\mathrm{AC}$ 票という）を同時に用いた調 查を実施する。PT 票と AC 票を比較し、目的別トリッ プ数の抜け落ちの程度、そして PT 調査票で抜け落ちる トリップが生じる要因について検討を行う。

キーワーズ：調查論、交通量計測、

*学生員、中央大学大学院理工学研究科土木工学専攻

（干112-8551 東京都文京区春日 1-13-27

TEL $03-3817$ - 1817 FAX 03-3817-1803)

**正会員、博(工学)、中央大学理工学部助教授

***正会員、工博、中央大学理工学部教授

\section{2. 調査の概要}

\section{（1）調査票}

本研究で用いた調查票は、既存の PT 調査票や社会生 活基本調查 ${ }^{5)}$ を参考に、独自に作成した調査票である。 調査票は PT 票と AC 票から成り立っており、折りたた むと $\mathrm{A} 5$ 大のサイズになる。回答者はまず $\mathrm{AC}$ 票を記入 し、その記入闌を両面テープで閉じてから PT 票を記入 する。すなわち PT 票の記入の際には、 AC 票の記入内 容を見ることはない。こうして本研究では、回答者がそ れぞれの調查を独立に回答した場合に近い状態になるよ う工夫した。また、回答者の抵抗バイアスを削減するた めに、調查票に記入する内容は本研究で必要とするトリ ップに関する以下のものに限定した。

$\mathrm{AC}$ 票 : 一日の活動の種類と活動時間

$\mathrm{PT}$ 票 : 移動に関しての出発地、出発時間、到着地、 到着時間、目的、利用した交通手段、自動車 の運転の有無

なお、調查票は匿名となるようにした。

\section{（2）調查}

まず、抜け落ちやすいトリップについての知見を得る とともに、後述する䛊差の検討方法の，有効性を確認する ためにプレ調査を行い、次に本調査を実施した。

(3) プレ調查

(a) 調查対象

カルチャースクールに通う 30 歳 40 歳代の女性の一 日の行動

(b) 調査日

1998 年 12 月 21 日（月）

(c) 配布方法・配布数

調查日の前日までに、調査対象者を訪問して 1 人 1 通 ずつ配布。配布数は 35 通。

(d) 回収方法 $\cdot$ 回収数 $\cdot$ 回収率

郵送による回収。回収数は 21 通。回収率は $60 \%$ 。

(4) 本調査

(a) 調查対象

中央大学土木工学科の学部生とその同居家族の一日の 行動。ただし、調查票を対象者本人に記入してもらうた 
め、同居家族は 15 歳以上の者とした。

(b) 調查日

1999 年 6 月 30 日（木）

(c) 配布方法・配布数

調査日の二日前に授業を通じて学生 80 名に、本人と 同居家族の分として 3 通ずつ配布した。配布する際に、 学生には以下のことをお願いした。

(1)調查票は 1 人 1 通とし、調査対象者本人が記入する こと(代筆は不可とする)。

(2)調查対象となる同居家族が本人を含め 3 人未満の場 合には、その人数分のみの配布でよいこと（例 1 人暮しの学生は、本人の分のみでよい)。

(3)調查対象となる同居家族が本人を含め 3 人以上の場 合には、任意の 3 人分でよいこと。

従って配布数は最大で、 80 名 $\times 3$ 通の 240 通となった。

(d) 回収方法 $\cdot$ 回収数 $\cdot$ 回収率

配布日から一週間後の 7 月 5 日（月）に授業終了後に 回収。回収数は 124 通。回収率は 240 通すべてを配布し たと仮定した場合において、51.7\%。

（5）プレ調查で得られた知見を確認するための調査 プレ調査により、回答者の意識や行動特性が PT 票の トリップの抜け落ちに影響を与えている可能性が明らか となった。そこで、本調查においては上記の調査票とと もに、性別、年齢、職業に加えて、以下に述べる質問を 加えた簡単なアンケートを本調査と同時に実施した。

(1)AC 票と PT 票のどちらが記入しやすかったか。

(2)一日の行動について、「いつ (時間)・どこで（場 所）・何をしていたか（目的」を正確に思い出すこ とは容易か。

(3)普段、目的地までの移動途中に、どこかに立ち寄る ことが多いか。

(4)同じ敷地や建物において異なった活動を連続して 行うことがあるか。

例 デパート内での買物と食事など

\section{3. 誤差の検討方法}

回収された調查票は、すべて有効データとして、以下 のように点検と修正を行う。その後、調查結果全体での 比較・検討、そして調查票単位での比較・検討を行う。

\section{（1）データの点検と修正}

以下のa）〜d）の段階に分けて、個々のデータを目 的別卜リップごとに点検と修正を行う。

a) 修正なし

$\mathrm{AC}$ 票 ; ・通勤・通学の欄に記入されているものを、 それぞれ通勤・通学トリップとして集計。

・移動の闌に記入されているものは、移動後 の活動内容が目的となるトリップとして、
目的別に集計。

PT 票 ; 目的の欄に記入された内容ごとに、目的別の トリップとして集計。

b) 一次修正（それぞれの調査票を独立に修正）

a)の段階での集計結果について、以下の修正を行う。

$\mathrm{AC}$ 票 ; ・前後に移動についての記入がなく、活動内

容が送迎となっているものについて、送迎

トリップとその次の活動内容を目的とする

トリップの 2 トリップがあるとして修正。

・異なる活動内容が連続しており、その間に、

移動が存在することが客観的に明らかな場 合に修正。

例 買物と自宅内での活動が連続して記入されて

いる場合には、その間に帰宅トリップが存在す

るものとして修正。

$\mathrm{PT}$ 票 ; ・送迎目的のトリップが 1 トリップとなって

いるものを、2トリップに修正。

c）二次修正（それぞれの調查票を独立に修正）

$\mathrm{AC}$ 票では時間軸が 10 分単位となっているために、 10 分以内の短時間の移動についての記入が漏れている可能 性がある。そこで、b）の段階での修正に加えて以下の 修正を行う。

$\mathrm{AC}$ 票; 異なる活動内容が連続して記入されている場合 には、その間に必ず、短時間の移動が生じて いると仮定して修正。

例 記入内容か、勤務、買物、食事と連続している場 合には、勤務と買物の間に買物を目的とする短時間の トリッブと、買物と食事の間に食事を目的とする短時 間のトリップが、それぞれ存在すると仮定して修正。

PT 票；b）の段階での集計結果を使用。

d) 比較修正（AC 票の記入内容と PT 票の記入内容と を比較して修正)

c）の段階における AC 票についての修正方法では、 実際には同一敷地内での異なる活動を行っていた場合 （例えば、デパート内での買物と食事）にも、移動が存 在しているものとしてトリップ数を過大に修正している 可能性がある。そこで、c)の段階での過大修正の可能性 を検討するために、b）の段階での修正に加えて以下の 修正を行う。

$\mathrm{AC}$ 票；c)の段階と同様の修正を行うが、 $\mathrm{AC}$ 票の記 入内容と PT 票の記入内容とが一致している 回答者は、移動（トリップ）についての認識 が正確であると考えられるため、 AC 票と PT 票の記入内容とを比較して、トリップの目的 や時間が一致している調查票については修正 しない。

PT 票； b ）の段階での集計結果を使用。

(2) 調査結果全体での比較・検討

a）〜d）の各段階において、目的別の一人当りの平 
均トリップ数と全目的の一人当りの平均トリップ数を求 め、 $\mathrm{AC}$ 票における集計結果と PT 票における集計結果 を比較する。AC 票と PT 票における集計結果に差があ るかどうかを七検定により検討し、PT 票におけるトリ ップの抜け落ちの程度やそのトリップ目的を把握する。

(3) 調查票単位での比較・検討

(a) 記入内容

回収された調査票ごとに、AC 票と PT 票の記入内容 が一致しているかを、以下のように分類する。

(1)修正する以前の段階（a）修正なしの段階）で、完 全に一致しているもの。

(2)修正する以前の段階（a）修正なしの段階）で、時 間についてはズレが生じているが、目的については 一致しているもの。

(3)互いに独立に修正した段階（c）二次修正の段階） で、一致しているもの。

(4)互いに独立に修正した段階（c）二次修正の段階） で、一致していないもの。

(b) トリップ数

(a) で AC 票と PT 票とで記入内容が一致しなかっ た調査票について、トリップ数に着目して以下のように 分類する。

(1)AC 票が PT 票を上回っている調査票

(2) $\mathrm{AC}$ 票と PT 票とで一致している調査票

(AC 票と PT 票とで互いに異なったトリップが抜 け落ちている結果、全体としてトリップ数が一致 してしまっている調査票)

(3) PT 票が AC 票を上回っている調査票

(c) 抜け落ちたトリップ

(b) で、 (1)AC 票が PT 票を上回っている調査票に 分類されたものは、PT 票においてトリップが抜け落ち ている調査票といえる。そこで、これらの調査票に着目 して、PT 票で抜け落ちたトリップがどのようなもので あるか分析する。

(d) 発生要因

PT 票でトリップの抜け落ちがどのような発生要因で 生じているかについて、調查票数とトリップ数の観点か ら検討する。

\section{PT 票におけるトリップの抜け落ちの発生要因}

本研究では、PT 票においてトリップが抜け落ちる要 因を以下のように整理した。

<トリップが抜け落ちる要因 $>$

A）回答者の記憶＝思い出しの段階

(1)回答者がトリップとして認識していない

（定常的な動き以外のトリップ、軽易なトリップ） (2)回答者の記憶があいまい

1）時間に対して
2 ) 到着地や目的に対して

B) 回答者の意志 $=$ 記入の段階

(3)回答者がトリップを省略

1）知られたくないトリップを故意に省略

2) 記入量が多く、面倒

3) 目的地の所在地名が分からない

(4)調査票の記入の仕方に対する理解不足

C) 外的要因

(5)代筆者による記入

\section{5.プレ調查における集計・分析の結果}

プレ調査においては、サンプル数が少ないながらも以 下のことが確認できた。

・ AC 票と PT 票でトリップ数に差があり、PT 票におけ るトリップの抜け落ち率は、おおよそ $15 \%$ あるる。 ・PT 票で抜け落ちるトリップは、帰宅途中の買物トリ ップ、䚻宅後の再外出トリップ、短時間の移動トリッ プの 3 種類しかなかった。プレ調査における回答者(調 査対象者）が 30 歳〜 40 歳代の女性のみであることが 一因と考えられる。

・抜け落ちるトリップについての発生要因としては、回 答者がトリップとして認識していないことが多い。 従って、本研究における調查方法は、PT 調查におい て抜け落ちるトリップが、(1)どの程度あるのか、(2)どの ような種類のものであるのか、(3)どのような要因のもと で発生するのか、についての分析を行うのに十分に有効 であると判断した。

\section{6. 本調查における集計・分析の結果}

\section{(1) 集計結果}

3.（1）で述べたa）〜d）の段階における集計結 果を表 1 に示す。ただし本調査の a）修正なしの段階の 集計を行っている時点で、回答者によって、勤務先や学 校から自宅までの移動について、通勤や通学とする回答 と帰宅とする回答があった。そこで、本研究の集計では、 b〜d）の段階においては以下の定義を用いる。

定義 ・ 勤務先への移動についての目的を通勤とする。 ・学校への移動についての目的を通学とする。

・自宅への移動についての目的を州宅とする。

（2）調查結果全体での比較・検討

全目的での一人当たりの平均トリッブ数を、 $\mathrm{AC}$ 票と PT 票で比較し、検討した結果を、表 2 に示す。ここで、 PT 票のトリップの抜け落ちる割合を次のように定義し、 c）２次修正、d）比較修正の各段階における抜け落ち 率を計算した。 
表 1 目的別平均トリップ数

\begin{tabular}{|c|r|r|r|r|r|r|r|r|}
\hline \multirow{2}{*}{ 目的 } & \multicolumn{1}{|c|}{ a)修正なL } & \multicolumn{2}{|c|}{ b)1次修正 } & \multicolumn{2}{c|}{ c) 2次修正 } & \multicolumn{2}{|c|}{ d)比較修正 } \\
\cline { 2 - 10 } & \multicolumn{1}{|c|}{ AC } & \multicolumn{1}{c|}{ PT } & \multicolumn{1}{c|}{ AC } & \multicolumn{1}{c|}{ PT } & \multicolumn{1}{c|}{ AC } & \multicolumn{1}{c|}{ PT } & AC & \multicolumn{1}{c|}{ PT } \\
\hline 通勤 & 0.95 & 0.57 & 0.52 & 0.54 & 0.65 & 0.54 & 0.60 & 0.54 \\
\hline 通学 & 0.61 & 0.37 & 0.37 & 0.36 & 0.48 & 0.36 & 0.42 & 0.36 \\
\hline 㷌宅 & 0.46 & 0.86 & 1.29 & 1.03 & 1.26 & 1.03 & 1.26 & 1.03 \\
\hline 買物 & 0.28 & 0.38 & 0.40 & 0.41 & 0.44 & 0.41 & 0.44 & 0.41 \\
\hline 社交·食事 & 0.18 & 0.20 & 0.25 & 0.19 & 0.54 & 0.19 & 0.42 & 0.19 \\
\hline 趣味·娛楽 & 0.04 & 0.08 & 0.11 & 0.08 & 0.16 & 0.08 & 0.15 & 0.08 \\
\hline 送迎·通院·学習 & 0.05 & 0.17 & 0.12 & 0.13 & 0.15 & 0.13 & 0.14 & 0.13 \\
\hline 販売·配達 & 0 & 0.40 & 0.01 & 0.04 & 0.03 & 0.04 & 0.03 & 0.04 \\
\hline 会議·打合せ & 0.02 & 0.40 & 0.03 & 0.03 & 0.07 & 0.03 & 0.05 & 0.03 \\
\hline 作業·修理 & 0.02 & 0.02 & 0.04 & 0.03 & 0.04 & 0.03 & 0.04 & 0.03 \\
\hline 農林漁業 & 0 & 0 & 0 & 0 & 0 & 0 & 0 & 0 \\
\hline 他 & 0.15 & 0.13 & 0.21 & 0.17 & 0.23 & 0.17 & 0.23 & 0.17 \\
\hline 計 & 2.77 & 2.86 & 3.32 & 3.02 & 4.06 & 3.02 & 3.76 & 3.02 \\
\hline
\end{tabular}

表 2 全目的での平均トリップ数の差についての検定

\begin{tabular}{|c|c|c|c|c|c|}
\hline \multicolumn{2}{|c|}{ 段階 } & \multirow{2}{*}{$\begin{array}{c}\begin{array}{c}\text { 全目的での平 } \\
\text { 均トリップ数 }\end{array} \\
2.77 \\
\end{array}$} & \multirow{2}{*}{$\frac{\text { 分散 }}{2.72}$} & \multirow{3}{*}{$\begin{array}{l}\mathrm{t} \text { 值 } \\
0.43\end{array}$} & \multirow{3}{*}{\begin{tabular}{|c} 
信頼水準 \\
$33 \%$ で有意差あり
\end{tabular}} \\
\hline \multirow{2}{*}{ a) } & $A C$ 票 & & & & \\
\hline & PT 票 & 2.86 & 2.56 & & \\
\hline \multirow{2}{*}{ b) } & $A C$ 票 & 3.32 & 3.40 & \multirow{2}{*}{1.37} & \multirow{2}{*}{ 82\%で有意差あり } \\
\hline & PT 票 & 3.02 & 2.50 & & \\
\hline \multirow{2}{*}{ c) } & $\mathrm{AC}$ 票 & 4.06 & 4.27 & \multirow{2}{*}{4.46} & \multirow{2}{*}{ 99\%で有意差あり } \\
\hline & PT 票 & 3.02 & 2.50 & & \\
\hline \multirow{2}{*}{ d) } & $A C$ 票 & 3.76 & 4.32 & \multirow{2}{*}{3.16} & \multirow{2}{*}{ 99\%で有意差あり } \\
\hline & PT 票 & 3.02 & 2.50 & & \\
\hline
\end{tabular}

表 3 過大修正の検討

\begin{tabular}{|c|c|c|c|c|}
\hline 段階 & $\begin{array}{c}\text { 全目的での } \\
\text { 平均トリッブ数 }\end{array}$ & 分散 & $\mathrm{t}$ 值 & $\begin{array}{l}\text { 信頼 } \\
\text { 水準 }\end{array}$ \\
\hline c) $\mathrm{AC}$ 票 & 4.06 & 4.27 & \multirow{2}{*}{1.13} & \multirow{2}{*}{$\begin{array}{c}74 \% て ゙ ~ \\
\text { 有意差 } \\
\text { あり }\end{array}$} \\
\hline d) $\mathrm{AC}$ 票 & 3.76 & 4.32 & & \\
\hline
\end{tabular}

PT 票のトリップの抜け落ち率

$=(\mathrm{AC}$ 票でのトリップ数-PT 票でのトリッブ数 $) /$

(PT 票でのトリップ数)

その結果、PT 票でのトリップの抜け落ち率は、c）

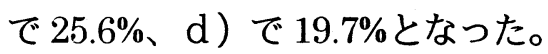

c ）の段階における修正方法では、 $\mathrm{AC}$ 票のトリップ 数を過大に修正している可能性がある。そこで、c）と d）の 2 つの段階での $\mathrm{AC}$ 票のトリップ数を比較するこ とで、過大修正についての検討を行う。比較した結果を 表了に示す。

表1〜3より、次のことが分かる。

・AC 票においては集計の際に何らかの修正が必要とさ れるか、PT 票よりもトリッブを詳細にとらえられる ということは、従来の調查結果と一致する（表 1)。

- c ）とd）の段階で AC 票でのトリップ数と PT 票で のトリップ数に有意な差がみられる。すなわち、PT 票でのトリップの抜け落ちが確認された（表 2)。

・PT 票のトリップの抜け落ち率は、c）、d）の各段階 の結果から、20\%程度であると推測される。

・社交・食事、趣味・娛楽を目的としたトリップが抜け やすい。

- c ）二次修正の段階における過大修正の検討について は、表 3より両者に有意な差があるかどうかの判断は 微妙な所である。このことから、これ以降の分析にお いてはc）二次修正の段階での集計デー夕を使用する が、c）の段階での集計結果には、過大に修正してい る可能性があることに注意する必要がある。

（4）調查票単位での比較・検討

(a) 記入内容

回収された調査票ごとに、AC 票と PT 票の記入内容 が一致しているかを、3.（3）で述べた基準に従って、 表4のように整理した。

その結果、トリップの目的とトリップ数が一致してい るものは、 124 票中 68 票 $(54.8 \%)$ であった。 
表 4 調査票ごとのトリップの内容

\begin{tabular}{|c|c|c|c|}
\hline \multicolumn{2}{|r|}{$\begin{array}{c}\mathrm{P} \text { T票と AC 票との } \\
\text { 比較基準 }\end{array}$} & \multicolumn{2}{|c|}{$\begin{array}{c}\text { 調査票数 } \\
\text { （全体に対する割合 ; \%) }\end{array}$} \\
\hline \multirow{3}{*}{ 一 } & (1)完全に一致 & $\begin{array}{l}14 \\
(11.3 \%)\end{array}$ & \multirow{3}{*}{$\begin{array}{l}68 \\
(54.8 \%)\end{array}$} \\
\hline & $\begin{array}{l}\text { (2)時間軸のみに } \\
\text { ズレあり }\end{array}$ & $\begin{array}{l}6 \\
(4.8 \%)\end{array}$ & \\
\hline & $\begin{array}{l}\text { (3)それぞれから } \\
\text { 独立に、修正可能 }\end{array}$ & $\begin{array}{l}48 \\
(38.7 \%)\end{array}$ & \\
\hline & $(4) 1$ - $=$ 致 & \multicolumn{2}{|c|}{$56 .(45.2 \%)$} \\
\hline
\end{tabular}

以下、 $\mathrm{P}$ T票と $\mathrm{AC}$ 票とで一致しなかった調査票 56 通についてより詳しく分析する。

(b) トリップ数

トリップ数に着目すると以下のようになる。

(1)AC 票が PT 票を上回っている調査票

‥ 44 通（全体の $35.5 \%$ )

(2)AC 票と PT 票とで一致している調査票

$$
\text { ‥ } 10 \text { 通 (全体の } 8.1 \% \text { ) }
$$

(3) PT 票が AC 票を上回っている調查票

$$
\cdots 2 \text { 通（全体の } 1.6 \% \text { ) }
$$

（c）抜け落ちたトリップの内容

(b)の(1)に当てはまる 44 通を PT 票でトリップが抜 け落ちている調査票とする。その内容ついては、図1に 示す6つに分類された。

(d) 発生要因

(b) で(1)AC 票が PT 票を上回っている調査票、す なわちPT票でトリップが抜け落ちている調查票 44 通を 対象に、次に述べる基準に従ってトリップが抜け落ちる 発生要因別に分類した。

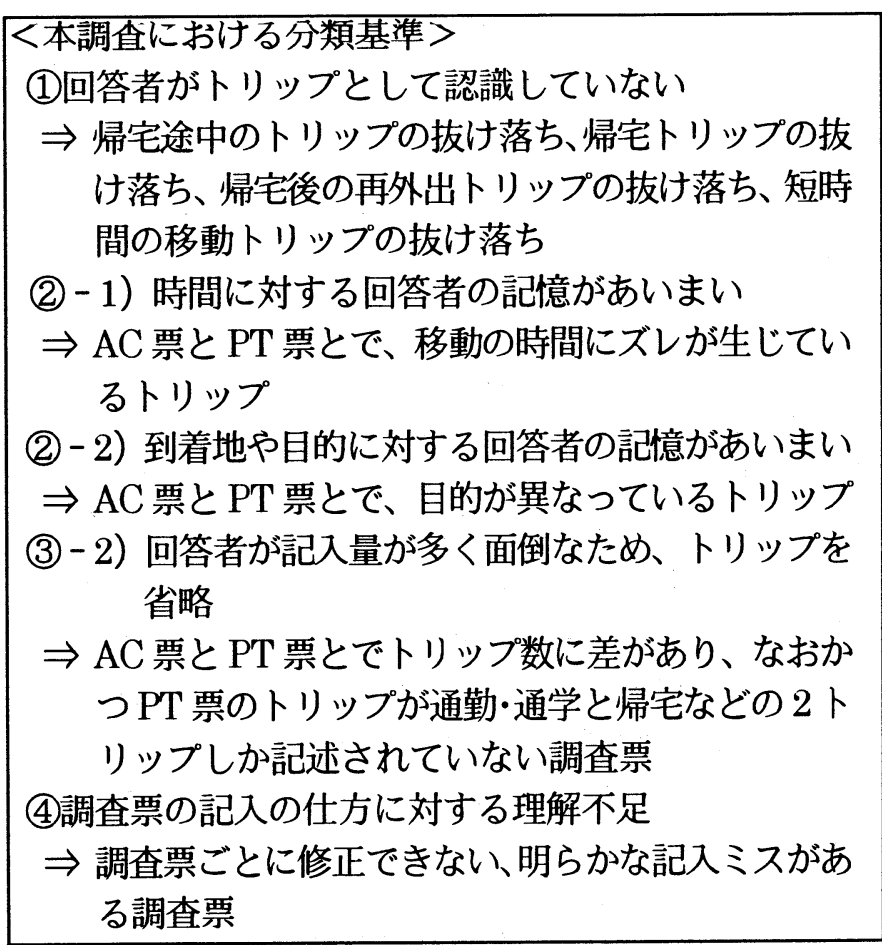

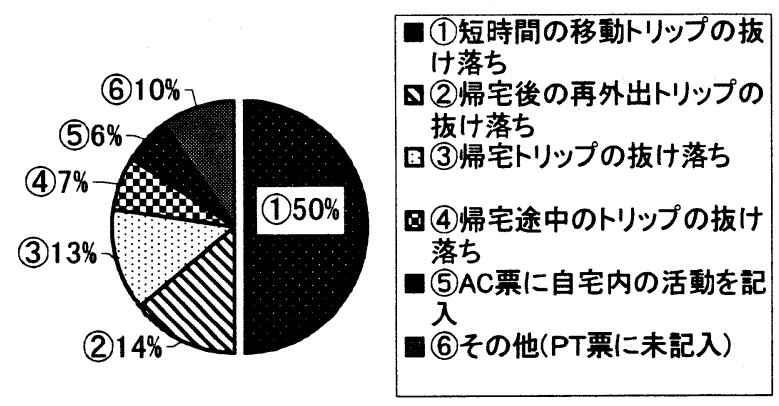

図1 PT票で抜け落ちたトリップの内容

発生要因ごとに分類した、調查票数とトリップ数をそ れぞれ表 5、6にまとめる。なお、各項目に当てはまる ものを重複して集計した。

調査票単位での比較・検討の結果から、以下のことが 分かる。

・AC 票と PT 票との記入内容が一致しない調査票が、 40\%以上もある（表 4)。

- a ）修正なしの段階で完全に一致している調査票はわ ずか $10 \%$ 程度である。つまり、回答者が調查票やトリ ップについて完全に理解できている人がほとんどいな い(表4)。

・トリップ数について、AC 票が PT 票を上回っている 調査票、すなわち PT 票においてトリップの抜け落ち が存在する調査票は、30\%以上存在する。

・抜け落ちるトリップとしては、鹵宅途中のトリップ、 帰宅トリップ自体、帰宅後の再外出トリップなどの严 宅に関連して発生するトリップの割合が大きい。なお、 短時間の移動トリップが抜け落ちたトリップの半数を しめているが、c) の段階の集計では、短時間の移動卜 リップを過大に集計している可能性があることに留意 する必要がある（図1）。

・抜け落ちるトリップについての発生要因としては、回 答者がトリップとして認識していないことが多い。 ・回答者が記入するトリップを省略している場合につい て考えると、表 5 と表 6 を比較して、全体で 63 (トリ ップ）を 24 (人) が省略したことになる。1人の回答 者 (調査票 1 通) につき、 2.62 (トリップ/人) もの 省略があることになる。

\section{7. 回答者の意識・行動特性と PT 票におけるトリップ の抜け落ちとの関係}

プレ調査における集計・分析から、帰宅に関連した卜 リップが抜け落ちやすいこと、またトリップが抜け落ち る要因としては、回答者がトリップとして認識していな いことなどが判明した。従って本調査を実施する時点に おいて、(1)調査票の記入のしやすさ、(2)思い出しやすさ、 といった回答者の意識や、(3)移動途中での立ち奇りの有 無、(4)連続した活動の多寡、といった回答者の行動特性 
表 5 発生要因ごとに分類した調査票数とその割合

\begin{tabular}{|c|c|c|c|c|c|}
\hline \multicolumn{2}{|c|}{ 発生要因 } & \multicolumn{2}{|c|}{ 調査票数 } & \multicolumn{2}{|c|}{ 有効調査票に対する割合 } \\
\hline \multirow{4}{*}{$\begin{array}{l}\text { (1)回答者がトリップとして } \\
\text { 認識していない }\end{array}$} & 帰宅途中のトリップ & \multirow{4}{*}{55} & 9 & \multirow{4}{*}{$44.4 \%$} & $7.3 \%$ \\
\hline & 帰宅トリップ & & 11 & & $8.9 \%$ \\
\hline & 再外出トリップ & & 7 & & $5.6 \%$ \\
\hline & 短時間のトリップ & & 28 & & $22.6 \%$ \\
\hline \multicolumn{2}{|c|}{ (2) - 1)時間に対する回答者の記憶があいまい } & \multicolumn{2}{|c|}{33} & \multicolumn{2}{|c|}{$26.6 \%$} \\
\hline \multicolumn{2}{|c|}{ (2) - 2)到着地や目的に対する回答者の記憶があいまい } & \multicolumn{2}{|c|}{22} & \multicolumn{2}{|c|}{$17.7 \%$} \\
\hline \multicolumn{2}{|c|}{ (3) - 2)回答者が、記入量が多いので面倒なためにトリップを省略 } & \multicolumn{2}{|c|}{24} & \multicolumn{2}{|c|}{$19.4 \%$} \\
\hline \multicolumn{2}{|c|}{ (4)調査票の記入の仕方に対する理解不足 } & \multicolumn{2}{|c|}{9} & \multicolumn{2}{|c|}{$7.3 \%$} \\
\hline
\end{tabular}

表 6 発生要因ごとに分類したトリップ数とその割合

\begin{tabular}{|c|c|c|c|c|c|}
\hline \multicolumn{2}{|c|}{ 発生要因 } & \multicolumn{2}{|c|}{ トリップ数 } & \multicolumn{2}{|c|}{ 総トリップ数に対する割合 } \\
\hline \multirow{4}{*}{$\begin{array}{l}\text { (1)回答者がトリップとして } \\
\text { 認識していない }\end{array}$} & 帰宅途中のトリップ & \multirow{4}{*}{102} & 9 & \multirow{4}{*}{$20.3 \% *_{1}$} & $1.8 \% *_{1}$ \\
\hline & 帰宅トリップ & & 15 & & $3.0 \% *_{1}$ \\
\hline & 再外出トリップ & & 16 & & $3.2 \% *_{1}$ \\
\hline & 短時間のトリップ & & 62 & & $12.3 \% *_{1}$ \\
\hline \multicolumn{2}{|c|}{ (2) - 1)時間に対する回答者の記憶があいまい } & \multicolumn{2}{|c|}{55} & \multicolumn{2}{|c|}{$14.7 \% * 2$} \\
\hline \multicolumn{2}{|c|}{ (2) - 2)到着地や目的に対する回答者の記憶があいまい } & \multicolumn{2}{|c|}{31} & \multicolumn{2}{|c|}{$8.3 \% * 2$} \\
\hline \multicolumn{2}{|c|}{ (3) - 2)回答者が、記入量が多いので面倒なためにトリップを省略 } & \multicolumn{2}{|c|}{$63^{* *}$} & \multicolumn{2}{|c|}{$12.5 \% *_{1}$} \\
\hline \multicolumn{2}{|c|}{ (4)調査票の記入の仕方に対する理解不足 } & \multicolumn{2}{|c|}{-} & \multicolumn{2}{|c|}{-} \\
\hline
\end{tabular}

**;トリップ数= ( $\mathrm{AC}$ 票中のトリップ数 $-\mathrm{PT}$ 票中のトリップ数 $)$

* $1 ； \mathrm{C})$ の段階での $\mathrm{AC}$ 票での総トリップ数を分母とする

* 2 ;C) の段階での PT 票での総トリップ数を分母とする

*1 と*2で分母が異なるのは、(2) - 1) や(2) - 2) に分類されるトリップはPT 票において抜け落ちているのではなর、 PT 票と AC 票の両者に存在し、それぞれ内容が異なるものであり、それらの割合を示すためである。

が PT 票のトリップの抜け落ちに影響を与えているとい う仮説が成立する。

そこで、本調査ではこの仮説を検討するために、 2 .

（5）で述べた質問に対する回答に着目して、AC 票と PT 票の平均トリップ数の差、そして PT 票のトリップの 抜け落ち率との関連性を分析した。

\section{（1）記入のしやすさ}

$\mathrm{AC}$ 票と PT 票とで、どちらの方が記入しやすいかに ついての回答の割合は以下の通りである。

・ AC 票の方が記入しやすい …5 59.7\%

・PT 票の方が記入しやすい $\cdots 29.8 \%$

・どちらでもない

... $10.5 \%$

これらの回答者ごとに、c）二次修正の段階における 全目的での平均トリップ数と PT 票でのトリップの抜け 落ち率を比較したものが表 7である。

$\mathrm{PT}$ 票を記入しやすいと感じている人の方が、 $\mathrm{AC}$ 票を 記入しやすいと感じている人よりも全目的の平均トリッ
プ数が少ないのにもかかわらず、PT 票でのトリップの 抜け落ち率が大きいことが分かる。

（2）記憶の思い出しやすさ

一日の行動を正確に思い出すことが簡単かどうかに ついての回答の割合は以下の通りである。

•簡単 $\quad \cdots 75.4 \%$

・難しい $\quad \cdots 14.4 \%$

・どちらでもない $\cdots 10.2 \%$

(1)記入のしやすさ同様に、これらの回答者ごとに、 全目的での平均トリップ数と PT 票でのトリップの抜け 落ち率を比較したものが表8である。

一日の行動を正確に思い出すことが簡単だと感じてい る人の方が、PT 票でのトリップの抜け落ち率が高い。

これらより、本人の無意識下でトリップを省略してい る可能性が高い。

（3）移動途中での立ち寄りの有無 
表 7 記入のしやすさとトリップの抜け落ち

\begin{tabular}{|c|c|c|c|}
\hline \multicolumn{2}{|l|}{} & $\begin{array}{c}\text { AC 票の方が } \\
\text { 記入しやすい }\end{array}$ & $\begin{array}{c}\text { PT 票の方が } \\
\text { 記入しやすい }\end{array}$ \\
\hline \multirow{2}{*}{$\begin{array}{c}\text { 全目的 } \\
\text { 平均ト } \\
\text { リップ }\end{array}$} & $\mathrm{PT}$ 票 & 3.24 & 2.60 \\
\cline { 2 - 4 } & $\mathrm{AC}$ 票 & 4.16 & 3.95 \\
\hline $\begin{array}{c}\mathrm{PT} \text { 票のトリップ } \\
\text { の抜け落ち率 }\end{array}$ & 0.27 & 0.52 \\
\hline
\end{tabular}

表 8 記憶の思い出しやすさとトリップの抜け落ち

\begin{tabular}{|c|c|c|c|c|}
\hline \multicolumn{2}{|c|}{ 思い出しやすさ } & 簡単 & どちらで & 難しい \\
\hline \multirow{2}{*}{$\begin{array}{l}\text { 全目的 } \\
\text { 平均卜 } \\
\text { リップ }\end{array}$} & PT 票 & 2.92 & 3.33 & 3.24 \\
\hline & $\mathrm{AC}$ 票 & 4.12 & 3.92 & 3.88 \\
\hline \multicolumn{2}{|c|}{$\begin{array}{c}\mathrm{PT} \text { 票のトリップ } \\
\text { の抜け落ち率 }\end{array}$} & 0.41 & 0.16 & 0.20 \\
\hline
\end{tabular}

目的地までの移動途中で、どこかへ立ち寄ることがあ るかどうかについての回答の割合は以下の通りである。

・ある $\cdots 78.7 \%$

•ない …21.3\%

同様にこれらの回答者ごとに、全目的での平均トリッ プ数と PT 票でのトリップの抜け落ち率を比較したが、 目的地までの移動途中で、どこかへ立ち寄ることがある かどうかにあまり関係ないという結果となった(表 9)。

\section{（4）連続した活動の頻度}

同じ敷地や建物において異なった活動を連続して行う ことが多いかどうかについての回答の割合は以下の通り である。

•多い ‥ $76.0 \%$

・少ない …24.0\%

同様に整理し、表 10 に示す結果を得た。これより、同 じ敷地や建物において異なった活動を連続して行うこと が多い人は、PT 票でのトリップの抜け落ち率も大きい ことが分かる。また $\mathrm{AC}$ 票は c) 二次修正の段階におい て、短時間の移動を若干、過大に修正している可能性が ある。

\section{8. まとめ}

本研究は $\mathrm{AC}$ 票と比較することで、PT 票において生 じる非標本誤差の一つである回答誤差（トリップの抜け 落ち）について、サンプル数が必ずしも十分ではなく、 また調査対象も特定の集団であるものの、以下の可能性
表 9 移動途中の立ち寄りとトリップの抜け落ち

\begin{tabular}{|c|c|c|c|}
\hline \multicolumn{2}{|c|}{ 移動途中の立ち寄り } & ある & ない \\
\hline $\begin{array}{c}\text { 全目的 } \\
\text { 平均ト } \\
\text { リップ }\end{array}$ & $\mathrm{PT}$ 票 & 3.09 & 2.72 \\
\cline { 2 - 4 } & $\mathrm{AC}$ 票 & 4.21 & 3.60 \\
\hline $\begin{array}{c}\mathrm{PT} \text { 票のトリップ } \\
\text { の抜け落ち率 }\end{array}$ & 0.36 & 0.32 \\
\hline
\end{tabular}

表 10 連続した活動とトリップの抜け落ち

\begin{tabular}{|c|c|c|c|}
\hline \multicolumn{2}{|c|}{$\begin{array}{c}\text { 異なった活動を } \\
\text { 連続して行うこと }\end{array}$} & 多い & 少ない \\
\hline $\begin{array}{c}\text { 全目的 } \\
\text { 平均ト } \\
\text { リップ }\end{array}$ & $\mathrm{PT}$ 票 & 3.17 & 2.54 \\
\cline { 2 - 4 } & $\mathrm{AC}$ 票 & 4.35 & 3.18 \\
\hline $\begin{array}{c}\mathrm{PT} \\
\text { 票でのトリップ } \\
\text { の抜け落ち率 }\end{array}$ & 0.38 & 0.25 \\
\hline
\end{tabular}

が存在することは明らかにできたと考える。

(1)PT 票におけるトリップの抜け落ち率は、おおよそ 20\%である。

(2)PT 票におけるトリップの抜け落ちは、主に帰宅に関 連したトリップである。

(3)PT 票でのトリップの抜け落ちの発生要因としては、 回答者がトリップとして認識していないことが多い。 (4)回答者が記入ずるトリップを省略している場合には、 回答者 1 人当たりに省略されるトリップ数が多い。

土木工学科の学生とその家族を対象とすることで、一 般回答者よりも調査に対して協力的であることと、トリ ップ概念に対する理解度が高いと考えられる。従って、 一般回答者を対象とした場合には本研究で得られた䛊差 が拡大することが予想される。今後、対象を拡大して同 様の調査・分析を行う必要がある。また、PT 票で抜け 落ちるトリップがどういった交通手段によるものか、ど れくらいの移動時間であるのか、についても明らかにす る必要がある。

さらに、トリップ数が多い人の特性や PT 票で抜け落 ちるトリップの特性を把握した上で、PT 調查の回答率 や精度の向上・補正方法についての検討、また OD 表な どから得られる外部デー夕を用いた交通現象に対する新 たな調查手法の開発についての検討を行う予定である。

謝辞 : 調査票の作成及びプレ調査の実施にあたり、協力し て頂いた 岸上博史氏 に感謝いたします。 
参考文献

1) 島崎敏一(1999) : パーソントリップ調査の問題点とそ の改善策 - 被験者の立場から、第 26 回関東支部技術 研究発表会講演概要集、pp.700-701

2 ）杉恵頼寧(1988): 交通行動調査の開発と適用 (その 2 )、 交通工学第 23 巻増刊号、pp.71-79

3 ）末永勝久、杉恵頼寧、藤原章正(1988) : 活動日誌を用 いた交通行動調査の有効性、土木学会年次学術講演概 要集、pp.186-187

4) 中村文彦、内田敦子、大蔵泉(1997) : アクティビティ ダイアリ調査を用いた郊外部の週末交通行動分析に関 する一考察、第 17 回交通工学研究発表会論文報告集、 pp. $213-216$

5 ）総務庁統計局(1998)、平成 8 年度社会生活基本調査の 概要

パーソントリップ調査における回答誤差とその発生要因

名取義和、谷下雅義、鹿島茂

本研究は、パーソントリップ調査の回答誤差 (トリップの抜け落ち) とその発生要因を明らかにするために、 パーソントリップ調査とアクティビティ・ダイアリ一調査を同時に実施し、その比較分析を行うものである。 その結果、パーソントリップ調査におけるトリップの抜け落ち率はおおよそ $20 \%$ であこと、主に帰宅に関 連したトリップが抜け落ちやすいこと、そしてそれらは回答者がトリップとして認識していないことから生 じていることなどを示した。

\section{Response Bias in Person Trip Surveys}

By Yoshikazu NATORI, Masayoshi TANISHITA and Shigeru KASHIMA This paper aims to describe characteristics of the trips omitted by respondents in person trip survey. We carried out original survey in order to compare person trip survey with activity survey. The results are followings; 1) about $20 \%$ of trips in a person trip survey are omitted; 2) omitted trips are related to going home trip; 3) omitted trips are not aware clearly as travel event by respondents. 